\title{
What do religion and natural science each have to say about origins, creation and evolution?
}

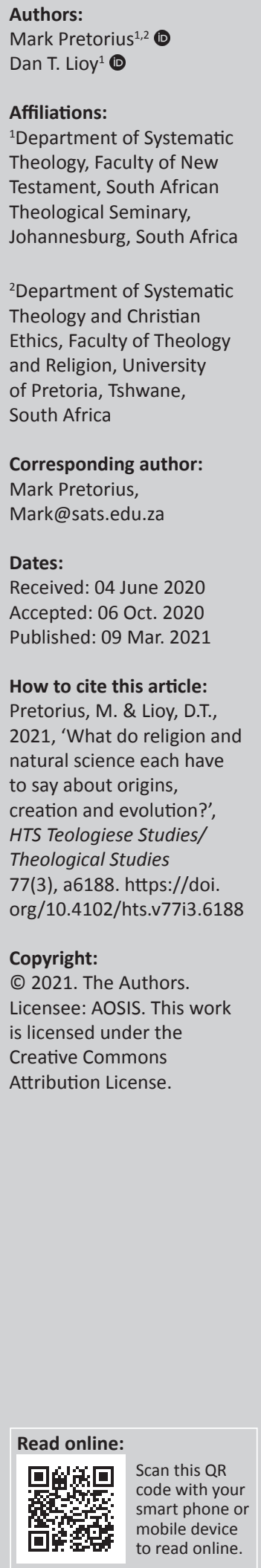

The purpose of this article is to put forward an acceptable scriptural stance with respect to an evolutionary worldview. The authors posit that a theologically orthodox position can best be substantiated when the moral ideal embodied in Christ is the starting point for all deliberations. In light of this premise, the authors consider the following topics: the great divide between science and religion; the various theoretical shifts taking place on both sides of the science and religion arena concerning the veracity of evolution a substantive consideration of Darwin's evolutionary theory; the issue of whether Genesis is only a myth or a narration of literal, historical events and the profound implications of evolutionary theory for religious belief. The authors conclude that a choice does not have to be made between evolution and religion but between good and bad evolutionary theory and good and bad religious beliefs.

Contribution: The article's challenge is to not only show that science and theology are not in conflict, but also that ascribing to an evolutionary worldview when discussing God's creative acts, is also not in conflict with God's Word.

Keywords: creation and evolution; Darwin; Genesis; science and religion; fossils.

\section{Introduction}

The authors of this article favour a predominately classical, evangelical and orthodox interpretive approach to scripture. The latter theological stance affirms that God is sovereign and righteous. The implication is that, as Davies (1993:3) observes, 'Divine revelation, found in the canonical Scriptures of the Old and New Testaments' ultimately 'constitutes the "bottom line" of the decision-making process' when considering the efficacy of other confessional and scientific sources of information (cf. Lioy 2011:4). Moreover, God's Word is given pride of place when choosing interpretive options about the meaning of specific passages of scripture and embracing particular philosophical notions about the nature of reality.

Considering the preceding statements, it follows that any move towards an ethical worldview concerning evolution must uphold the supreme authority of God as testified in scripture. Accordingly, an evangelical Christian perspective will be posited, in opposition to the radically prevailing agnostic worldview regarding evolution. Our personal conviction is that the validity of a theologically orthodox position can best be substantiated when the moral ideal embodied in Christ is the starting point for all deliberations. With all that Christ entails as the central theme, it is possible to arrive at a code of ethics that offers practical direction for evangelical Christians concerning evolution. Because this approach originates from a starting point dissimilar to that of naturalism, God is the central point of reference. Likewise, God is the foundation of every moral requirement and supreme value.

Admittedly, there are challenges connected with developing an acceptable scriptural stance with respect to an evolutionary worldview. For instance, theologians immediately confront a society that incessantly expects them to discover methods of conforming the biblical narrative of creation to the evolutionary supposition of human origins and the aetiology of the cosmos. This circumstance leads specialists in biblical theology to the realisation that a significant separation has developed between their discipline and that of evolutionary science (both cosmic and biological; cf. Lioy 2011:2). Without question, if any complementarity is to be attained, meaningful dialogue between proponents of both disciplines is essential. 


\section{The seeming schism between religion and science}

Green (2004:168-169) rightly affirms the fact that the struggles on the contemporary theologian in academic life are exceptional, and he informs on various places where this takes place. Firstly, in recent decades, the staggering progress of the natural sciences and their growing expertise have surpassed several arts-related subjects, perhaps none more than religion. Green points to the many concepts being recommended in the flourishing world of science and technology that are disturbing to evangelical theologians. Briefly, there is a mood of enthusiasm about humanity in scientific circles, which has been encouraged by the relative success of the discipline. This contrasts the cynicism about humanity expressed in numerous arts circles as well as that upheld by the Christian doctrine stating people are fallen human creatures.

Secondly, Green remarks that in a modernised scientific community there is, at best, agnosticism about God. Allegedly then, a God of the gaps is unnecessary to plug the gaps in scientific knowledge. Thirdly, there seems to be impatience amongst scientists concerning miracles. Supposedly, because the world is a place of observed and dependable consistencies, direct divine intervention cannot be detected. Lastly, because there have been many futile debates in the past century between Christians and advocates of Darwin over Genesis and evolution, it is generally supposed in scientific circles that the Bible has been discredited. This is especially so concerning God's Word which is considered nothing more than a collection of myths, which science has now exceeded.

The preceding four premises are frequently and uncritically assumed, rather than explicitly declared, by numerous scientists. In turn, this stance poses a challenge today for evangelical theologians. Ross (2009:29) puts forward a cogent response that warrants mention. He notes that 'For thousands of years, scholars from various cultural and religious backgrounds have proposed intelligent design as an explanation for many observable properties of the universe'. Ross further states that 'For more than a century, every student at Cambridge University was required to study William Paley (1809)'s famous text Natural Theology', wherein the famous analogy of the watch was used to infer intelligent design. Indeed, prior to the work of Charles Darwin, the study of evolution was not considered a scientific discipline. Moreover, it is only in the last century that scholars and teachers have discarded intelligent design and adopted an evolutionary process to explain creation (cf. Ruse 1997).

Despite all the conflicts arising from the science and religion debate, all is not lost. Today, many scientists who study how nature impacts humankind, and vice versa, are also rethinking several of the evolutionary ideas being posited by natural scientists and theologians in academic journals around the world. Furthermore, over the centuries, through a select few highly publicised incidents, there is a perception that there is much disharmony and conflict between science and religion vis-à-vis evolution. As rightly expressed by Numbers (ed. 2009:1-7), Plantinga (2011:6) and Russell (1985:3), one only has to read the conflict thesis of Andrew Dickson White (1896) and Draper (1874) to see how the antagonism between the two disciplines developed. Then again, Giberson and Collins (2011:84) write that apart from the 'warfare metaphor' espoused by the books of White and Draper, science and religion, aside from a few skirmishes like the Galileo affair and a few others, were actually supportive of one another. Doubtless, many paradigm shifts are taking place on both sides of the science and religion continuum about the reality of evolution, which need to be brought to the fore, so that both sides can reach an allencompassing biblical ethics worldview.

\section{Paradigm shifts: Creation or evolution}

As proposed by Peterson (2000:221), the sorts of paradigm shifts mentioned in the preceding section 'are difficult and exhilarating experiences for those who encounter them'. According to the framework of Thomas Kuhn (1962-1970), a paradigm shift occurs because of the eruption of a crisis. Further, there are circumstance, according to Kuhn, '... when an old established theory becomes increasingly difficult to argue and must be overthrown by a newer, more intellectually savvy competitor'. Although Kuhn limited his observations to the fields of astronomy, physics and chemistry, the kind of competition he described can be seen in almost every natural scientific discipline. In fact, within the last century, the following seismic shifts in perspective have occurred, especially in astrophysics and other natural science studies. For example, an eternal steady-state view of the universe has now been replaced by the big bang model; in geology, the notion of static continents has been replaced by plate tectonics and in palaeontology, cold-blooded models of dinosaurs now compete with newer, warmblooded versions.

As further offered by Peterson (2000:222) and cited in Pretorius (2007:100), Peterson correctly states that whether one adheres to the details of Kuhn's philosophy of science or subscribes to later versions of the same, conflict is an essential staple of scientific discourse and development. For instance, through such conflicts, new theories are born and old ones die, though it may take decades for the transition to occur. For all that, the historical emergence of modern science has definitely marked a dramatic paradigm shift from a focus on the metaphysical question of being to the epistemological question of knowing. According to Clifford (1994:64), in descriptions of knowing advanced by proponents of modern science, the latter have claimed rational objectivity for science's knowledge. In turn, they have developed a dualism that separates humans from nonhuman nature. Moreover, according to these specialists, theories are objectively formulated from data derived from observations. 
Despite these sweeping assertions, the preceding construct has proven to be inadequate. Furthermore, the postmodern understanding of science is critical of any depiction of science that ignores the subjective perspective its practitioners bring to the discipline. In response to this legitimate assessment, a new form of critical realism has arisen (cf. Lioy 2011:12-13). Proponents of the latter recognise that when scientists interpret data, they are not detached, neutral spectators capable of total objectivity. As Toulmin (1982) so succinctly expressed:

The scientist as spectator is dead. In contrast to the Cartesian dualism found in modern science - which separates mind from matter, reason from emotion, and humanity from nature postmodern scientists are reinserted into the cosmos as embodied observers and participants of the unfolding drama they are observing. (p. 252)

The impact of postmodernism on science has created a new opportunity for meaningful dialogue between scientists and theologians. As revealed by Wolfhart Pannenberg (1988:3), the connection between science and theology was indicated by constant and mutual hostility from the 18th century to the beginning of the 20th century. However, it should be recognised that what Pannenberg referred to are well-publicised cases. As previously expressed, these have fuelled the idea that science and religion are in conflict.

Regrettably, these specific episodes in science and religion history have been played out countless times in seminars, books, articles and magazines, which tend to stimulate the idea that the conflict or independent models - as formulated by Ian Barbour (2000) - flourish between science and religion, and thus nothing in the future will change. However, it is the authors' contention that this perception is false. Essentially, there is now more dialogue and integration between science and religion than there has been in the last four centuries (cf. Alexander 2008; Barbour 2000; Clayton 1999; Collins 2003; Collins \& Giberson 2011; Dixon 2008; Ferngreen 2002; ed. Numbers 2009; Plantinga 2011; Polkinghorne 1998).

Furthermore, as the 21st century emerged, there have been serious efforts to bridge previous gaps that existed between scientists and theologians. As proffered by Pannenberg, these efforts began in England in the second half of the last century. Specifically, an attempt was made to offer a theologically positive evaluation of evolution. The goal was to integrate the latter into a Christian version of the world and salvation history.

The preceding endeavour should not lead to the incorrect conclusion that religion is succumbing to the onslaught of scientific discoveries. In order to provide a more balanced, informed and nuanced view of the science and religion debate around evolution, a substantive consideration of Darwin is warranted. Certainly, many regard him to be the father of the evolutionary view, even though this sentiment is rather inaccurate. That disclaimer notwithstanding, the following sections undertake and compare Darwin's theory of evolution to the biblical account of creation.

\section{Darwin's Fossil dilemma}

Ratzsch (1996:30) correctly perceived that Darwin was quite conscious about the fact that there were problems with his theory of evolution. In fact, his book The Origin of Species is not only full of diverse observational data but also catalogues key shortcomings of Darwin's theory. Moreover, in his treatise, he admitted that he could not answer some vexing scientific questions and suggested possible solutions to several of the unresolved issues. For example, Darwin acknowledged that if his theory were true, intermediate fossils should show the transition of one species into another (i.e. macroevolution). According to Rhodes (2004:31), at the time Darwin wrote his book, scientists had not discovered any intermediates. However, as Ratzsch (1996:33-34) states, Darwin did concede that the fossil record was sketchy and incomplete. Also, he expressed the hope that 1 day intermediates would be discovered. Furthermore, he suggested that the geological conditions under which a new species might emerge in a given area were such that fossilisation was not likely to occur. For this reason, the fossil records might contain less evidence of intermediates, as argued by Johnson (1998:29-30).

Whilst Darwin was puzzled over his lack of fossil evidence, the situation today - over a century after his time - is quite different. However, Darwin did acknowledge intermediates in his 1872 book The Descent of Man. Nevertheless, and according to Gould (2001:1), an abundance of fossils has been discovered. Indeed, there are virtually billions of them, which is more than enough to draw valid scientific conclusions. In particular, these data show rather conclusively that no intermediate fossils exist. Further to this, the fossil records show no evidence of simple life forms transitioning into complex life ones (2001:2). Rather, the evidence reveals a virtual explosion of animal phyla (i.e. divisions or 'types' of the animal kingdom) appearing during the Cambrian era. (The latter is named after Cambria, Wales, where massive fossil beds were discovered and studied in the 1800s.) A candid assessment of the data uncovers neither any true evolutionary ancestors in the PreCambrian era nor any genuinely new groups appearing in post-Cambrian times.

Moreover, researchers have uncovered fossils of more than a 100 species of soft-bodied animals, innumerable small-shelled organisms and other life forms. In reference to this, Gould (2001) stated the following:

In one of the most crucial and enigmatic episodes in the history of life, and a challenge to the old and congenial idea that life has progressed in a basically stately and linear manner through the ages, nearly all animal phyla make their first appearance in the fossil record at essentially the same time. (p. 251)

Many of the animal types that appear in the Cambrian Era continue to the present-day. 


\section{The foundation of Darwinism}

In the fourth chapter of The Origin of Species, Darwin presents the heart of his evolutionary theory, which he referred to as natural selection. He begins the chapter as follows:

$[H]$ ow will the struggle for existence act ... in regard to variation? Can the principle of selection, which we have seen is so potent in the hands of man, apply in nature? Let it be borne in mind in what an endless number of strange peculiarities our domestic productions ... vary; and how strong the hereditary tendency is.

Can it then be thought improbable, seeing that variations useful to man have undoubtedly occurred that other variations useful in some way to each being in the great and complex battle of life should sometimes occur in the course of thousands of generations? If such do occur, can we doubt (remembering that many more individuals are born than can possibly survive) that individuals having any advantage, however slight, over others, would have the best chance of surviving and of procreating their kind? On the other hand, we may feel sure that any variation in the least degree injurious would be rigidly destroyed. This preservation of favourable variations and the rejection of injurious variations, I call Natural Selection. (ed. Darwin 1996:67-68)

Gray, the American botanist, published in the American Journal of Science and Arts (6-91), a lengthy and cautious review of Darwin's The Origin of Species. In his review, Gray admits that not many would accept Darwin's ideas and mentions two prominent scholars, namely, the editor of the American Journal of Science, James Dwight Dana, a natural history professor at Yale University, and Louis Agassiz, an American naturalist. Gray further cites that according to Schwartz (1981:262), Agassiz indicated that the phenomenon of origin and distribution of the species was directly related to the divine will of God and, thus, could not accept Darwin's idea of natural selection.

Further to this, according to Moore (1979):

... for some Christian anti-Darwinians, the main theological objection to Darwin's theory lies in the perception that it undermined the idea of design in nature, thus bringing into question the very existence of God. (p. 103)

Actually, he goes on to say, '... there were many Victorians, steeped in Christian tradition, whose manuscripts and memoirs reveal a common struggle with the ideas and implications of Darwinism'.

To be fair, Darwin's theory of evolution seemed sensible in his day. As indicated by Russell (1985:146) and cited in Pretorius (2007:102-103), Darwin's hypothesis was based on the following three reasonable assumptions:

- Hyper productivity or (super-fecundity): Organisms produce more offspring than can reach maturity.

- Variability: A range of differences exist within any species (e.g. in anatomical details, which can determine, for example, the ability to see, move, digest, hide from predators, etc.); and,
- Natural Selection: Environmental change, food shortages and the presence of predators together create for a species a struggle for existence. The latter process gradually and inexorably weeds out the less well-adapted members through successive generations. The process also allows the better-adapted life forms to survive to the stage of procreation, and thus pass on their favourable characteristics.

As specified by Barrett (2004:92), it was the key insight of Darwin that guided him to combine variability and natural selection. Barrett clarifies that it is the numerous minor differences within a species that are decidedly important. The reason is they provide the necessary materials for natural selection to work on. Barrett uses the example of domestic animals or birds breeding, which show that accumulated individual differences by artificial selection can cause movement in different directions.

It would be incorrect to conclude from the preceding comments that the authors of this article are offering a defence of Darwinism. Rather it is to affirm that, as Schwartz (1981) correctly noted:

It must be added that Darwin's theory of evolution did not deny religion. Instead, it was a scientific theory grounded in science and thus, should only be scientifically contested. Further, Darwin's theory never disparages God's creative activity. Indeed, and as maintained by Van Till (1999:161), when interpreted theistically, Darwin's theory could even enrich one's awareness of the enormity of God's 'fully gifted creation', a term employed by Van Till (1999:162-197) in preference to the expression 'theistic evolution'. (p. 263)

Returning to the analysis offered by Gray (1878:61); in his view Darwin's theory of descent, or anything similar, was not yet ready to be accepted as factual and added that it may never prove to be true. Nevertheless, Gray did maintain that caution and care should be applied to any other claims that may attempt to explain that there are secondary causes for the presence of numerous types of plants and animals. However, after making these statements, Gray never wanted to appear reticent and impartial; rather, he wanted to ensure that the truths of science rested on proof that is unambiguous.

A working example would be Darwin's estimation that in the southern part of England, the rock strata were about 300 million years old, which he judged minor in geological history. Barrett (2004) observes that:

This theory was challenged by the formidable Scottish physicist, Sir William Thomson, who calculated that the cooling rate of the planet gave a reading of only about 100 million years. (p. 94)

Admittedly, Thomson did not have access to the findings of modern science from the 20th century. Today, and as specified by Schopf (2011:87-101) and Munro (2004:563), the earth is considered to be approximately 4500 million years old. This is a well-established figure confirmed by measuring 
the radioactive decay of ancient rocks and further reinforced by additional sources of data.

In summary, Darwin's theory is often seen as a puzzle with numerous central pieces missing, yet still having enough of the picture in place to support a wide range of phenomena. For example, the evolutionary hypothesis permitted him to describe his many wide-ranging and unique descriptions about the geographical spread of animals. Yet as noted by Barrett (2004:95), Darwin's theory 'provided a reasonable explanation of the countless number of remarkable examples of adaptation found in nature'.

Before ending this section, it is reasonable to discuss the nature of Darwin's legacy. Barrett (2004:109) points out that Darwin had studied widely. Accordingly, Darwin surprisingly flourished in making his findings available and understandable to a wide field of readers, concerning evidence that spanned many disciplines, involving geology, botany, taxonomy and morphology. His creative and understandable writing style meant that Darwin's work would spread widely and influence those beyond the concerns of just natural science. Eventually, his writings left their mark on philosophy, the social sciences and Victorian literature. Moreover, Darwin's theory raised fundamental questions about the beliefs that had been championed by Christian theologians. Even today, Darwin's work inspires a spectrum of academic endeavour. Indeed, it is a veritable Darwinian industry. Conversely, this leads to the contentious issue of the creation chapters of Genesis, and how they are to be understood in the light of science.

\section{Genesis Chapters 1-11: Truth or myth?}

Scholars such as C.J. Collins (2011:16-17) argue that the episodes recorded in Genesis narrate literal events and are foundational to all Christian doctrine. Expressed differently, all biblically based doctrines taught in Christian theology ultimately have their origin in Genesis, whether directly or indirectly. Therefore, a faith-based approach to Genesis is a prerequisite to an understanding of God and what God has communicated to humanity. As succinctly put by Ham (1987:71), 'If Genesis is only a myth or allegory, then Christian doctrines have no foundation'.

It is traditional to base an analysis of the biblical doctrine of creation primarily on the Genesis creation accounts, with which the Old Testament canon opens. Yet, as McGrath (2004:46) correctly argues, the theme of creation is deeply embedded throughout the historical, wisdom and prophetic literature, which are the three main types of writing (Torah, Prophets and Writings) found in the Old Testament. For example, Job 38:1-42:6 (traditionally regarded as a portion of the wisdom literature) sets out what is unquestionably the most comprehensive understanding of God as Creator to be found in the Old Testament. These chapters especially stress the role of
God as Maker and Sustainer of the world. A variety of Hebrew verbs are found in this extended passage, with slightly different overtones and embrace such notions as 'to make', 'to form', 'to establish', 'to create' and 'to found'.

When attention is shifted to the New Testament, one finds that the preceding theocentric emphasis is complemented by a Christotelic focus on creation. Christ the Son is revealed to be the divine agent of creation. Also, God is depicted as the eternally pre-existent logos through whom the world was created. Moreover, it is disclosed that Christ became incarnate as the Redeemer. Indeed, God alone established a link between the divine acts of creation and redemption.

Most classical expressions of Christian theology give much attention to the doctrine of creation which is often the first doctrine explored within systematic theology. According to McGrath (2004:52), the following two factors are of particular importance in relation to this development:

- Firstly, the major theological statement to be faced by any reader of the Bible is the doctrine of creation as set out in the canonical form.

- Secondly, the Nicene and Apostles' Creed which are both influentially recognised by the Church, begin by declaring God as Creator. Further, many classical systematic theologies frequently follow the creedal ordering of doctrinal affirmations which regularly place the teaching of creation at the beginning of theological inquiry.

In the view of Barker and Burdick (eds. 1985:2), Genesis fittingly lays an important foundation for understanding the rest of the Bible. Further, and as explained by Marshall (1998:1), the episodes recounted in Genesis tend to determine the foundation for the believer's personal understanding of God. Here, agreement can be achieved with Psalms 11:3, 'If the foundations are destroyed, what can the righteous do?' Stedman (1995:1) points out that in contrast to nonsensical myths about creation found in other ancient Near Eastern cosmological writings, such as those, according to Nelson and Reynolds (1999:62), found in the Enuma Elish, the Timaeus and the Epic of Gilgamesh, the Bible presents a clear and rational historical and metaphorical narrative of creation. These opening chapters explicitly show how God fashioned a perfect creation, how humanity rebelled against God's rule, causing the fall, and how after the rebellion, God brought judgement on human sin, culminating in the flood.

\section{Alternative views on genesis}

According to Barbour (2000:48), numerous theologians share the view that the Bible should be taken seriously, but not literally. These specialists, such as Borg (2003), Kennedy (2006) and Spangenberg (2003), as referred by Pretorius (2007):

[C]laim that Genesis witnesses to a fundamental and enduring relationship between God and the world by telling a symbolic and poetic story, one that assumes the prescientific cosmology of its day. (p. 116) 
Moreover, scripture communicates religious ideas that are still independently acceptable of any cosmology, whether ancient or modern. Barbour (1997) cited in Pretorius (2007) clarifies that within this context:

Genesis makes three key theological affirmations: firstly, the world is essentially good, orderly, and coherent; secondly, the world is dependent on God; and thirdly, God is sovereign, free, transcendent, and characterized by purpose and will. (p. 116)

At every moment in time, these are characteristics of God and the world God created, not just statements about past events.

The above notwithstanding, when all is said and done, one needs to come back to the scriptural account of creation. Indeed, to treat the book of beginnings as either allegory or myth renders all other scriptures null and void. For instance, how can one theologically grasp the significance of John 3:16, if one does not recognise the devastation of Adam's sin that was caused by him as the federal head, which represented all humankind before God in the Garden of Eden? Also, claiming Genesis to be just an allegory dilutes the doctrine of Christ's advent and His redemption of all humankind as the second federal head. Although this idea may be viewed as narrow and subject to criticism, the authors do hold to the inerrancy of scripture, and rather than employing a mythical model within which to interpret Genesis, a historical-metaphorical narrative is the preferred model.

From the preceding statements, the following question arises: What does the postmodern scientists have to say about the creation events narrated in Genesis? Earlier in this article, it was noted that in the past, scientists generally viewed 'reality' as being fixed, immutable and unaltered by the scientific enterprise. Yet, as Clifford (1994:65) avers, in postmodern science, it is more realistic to speak of any notion of reality as being created in part by the scientific community, a community affected by the broader society. As further specified by Clifford (1994:65) 'As participants in that society, scientists derive their theoretical metaphors from their culture and from their personal life experiences'.

In short, the scientists' views about the cosmos and its inherent processes are affected by the attitudes of the respective societies in which they live. Therefore, it is not only a matter of who is doing the research but also the when and where of their inquiries that have a direct bearing on the formation of scientific theories (cf. Bleier 1986; Harding 1986). Put simply, the endeavours and assertions of postmodern science are not autonomous from a society's social, political and religious interests and values (Clifford 1994:66). Expressed differently, Pretorius (2007:117) states 'scientific theorising is affected by its surrounding environment. This implies that rigid boundaries between scientific communities, the broader society, and its other communities can no longer be maintained'. Consequently, fertile and transforming discussions between science and religious groups concerning the cosmos are now more possible than ever before.

\section{Other important events in Genesis}

Genesis records other important events that are foundational to understand the rest of the Bible. By way of example, Genesis 22 shows the principle of substitutionary sacrifice. Genesis 3:15 gives the proto-evangel, which provides the first hint of God's plan of redemption for humankind. Over half of the famous 'faith-full' people recounted in Hebrews 11 are individuals first presented in Genesis, as are those in Matthew's and Luke's genealogies of Jesus (cf. eds. Barker \& Burdick 1985:2). The account of Abel's murder shows that life is precious (Gn 4:10-11; 9:6), that there is salvation from the consequences of the fall $(3: 15)$ and that humanity is to have a Sabbath rest (2:1-2). God's creation of Adam and Eve provides support for the biblical notion of a work ethic and stewardship of the earth $(1: 28 ; 2: 1-2)$. The basis for marriage is seen in the union of Adam and Eve $(1: 27-28 ; 2: 18 ; 3: 16)$. The fall and the Father's judgement are both central to the salvation later made possible in the Son (3:1-24). All of these teachings are threatened when Gn 1-11 is treated as either myth or allegory (cf. Pretorius 2011).

\section{The insidious consequence of alleging that Genesis is filled with myths}

Grudem (1994:287) explains that many Christian doctrines have their roots in the early chapters of Genesis. Consequently, if as Enns alleges (2012:137-138), Genesis contains fabricated tales, these key doctrines end up being built on an unstable theological foundation. Moreover, if Genesis does not provide an accurate historical account of beginnings, the only alternative is to believe in a somewhat misshapen Darwinian evolution. The latter undermines the view people have about the veracity and trustworthiness of scripture. In short, if there is no God who created humankind, or if nothing can be known about God with any certainty, then there is no supreme Judge who holds people morally accountable. Likewise, with the concept of 'survival of the fittest' driving all human decisions and leading to a Social Darwinism, there can be no moral absolutes to evaluate the nature of those choices. Furthermore, evolution, incorrectly understood, makes God unnecessary and impotent.

The preceding assertions are very different from the sovereign Creator revealed in Genesis. It is sensible, then, to hold that the events described in its opening chapters are historical-metaphorical, rather than mythological. Furthermore, it is important for evangelical Christians to 
understand and affirm the doctrines whose foundations are laid in Genesis. Indeed, without a proper comprehension of the nature of God, the literal fall of the first man named Adam, the inability of humanity to earn salvation through good works and the principle of substitutionary sacrifice, one can never fully appreciate the salvation revealed in the gospel about Christ. The preceding remarks argue well for a theistic outlook on creation. Similarly, and in the view of most evangelicals, a denial of these truths produces a weak gospel and an impotent God - one who seems to have lost control of his creation or has established laws that do not effectively govern the creation process. In light of this analysis, it is worth asking again whether religion in reality needs an evolutionary theory.

\section{Does religion need an evolutionary theory?}

According to Peterson (2000:223), it is traditionally 'assumed that evolutionary theory - and especially the theory of natural selection - has profound implications for religious belief'. Interestingly, this is an almost universally held supposition, irrespective of one's theological or philosophical range. Floyd (1999:24-31) states that militant atheists such as Richard Dawkins and Daniel Denett share with religious 'fundamentalists the view that evolution and religion are necessarily in conflict'. On the one hand, religious fundamentalists reject evolution because of their commitment to the belief that God created the earth in 6 literal (i.e. 24) days. In contrast, militant atheists assert that natural selection obviates the need for any all-knowing, absolutely powerful designer. Paradoxically, whilst atheists contend that evolution proceeds from the simple to the complex, they fail to grasp that a supreme, universal mind would be the most complex of all entities in the cosmos.

In the view of Peterson (2000:223), when one moves into the established ideas of theology, which mostly do not support a literal interpretation of the 6 days of Genesis, one often finds almost equal interest in evolution, although the reasons differ. Firstly, it is often supposed that Darwinian natural selection challenges established theistic design arguments for the existence of God. In this sense, the argument not only replaces God with a purposeless process but also gives the idea that the process seemingly goes nowhere in particular. Conversely, there is no room for a 'God-of-the-gaps'. Equally, limited evidence exists showing that the intention and focus of the evolutionary process was specifically designed for the emergence of Homo sapiens or any other particular organisms. Secondly, because human beings are allegedly products of evolution and natural selection, one could then argue that evolutionary theory can potentially make a noteworthy contribution to theories of human nature, a subject with which theology is profoundly concerned.

It is, therefore, not surprising that many in the science-religion dialogue have turned their attention to precisely the preceding kinds of issues (cf. Peacocke 1984; Rolston 2004; Ward 1998). In this vein, theologian Anna Case-Winters (1997:357) maintains that both science and theology, vis-à-vis evolution, do provide models that show concordance between the two disciplines. In her view, one could present it as follows:

- Science provides models of the way things are or how the world works.

- Scripture provides metaphors of reality (nature), or that which is the highest, best, and most valuable. These metaphors intend to present a true picture of the cosmos.

Inevitably, evolution matters to religion. Karl Popper, in one of his famous lectures stated, 'There can be no doubt that Darwin's theory of evolution by natural selection is of the greatest importance' (1994:52). Popper also wryly voiced in the same lecture that, "There can also be no doubt that this theory is, in many respects, in an unsatisfactory state'. As proposed by Pretorius (2007:106), 'The only means of escaping the ramifications of this conclusion is to deny the significance of origins and historicity'. He goes on to say 'Various forms of existentialism and existentialist theology accomplish this, but only at the expense of divorcing human spirit from biology' (Pretorius 2007:107).

One question that needs to be asked is: Is there any reason why theologians should give attention to other evolutionary theories? Some would argue that evolutionary theory often suggests specific kinds of claims which could relate to specific Christian doctrines and schools of thought. However, it must be noted that evolutionary theory cannot dogmatically state whether the universe or the appearance of civilisation are simply the outcome of chance or are a necessary product of chance. Nevertheless, and, according to Pretorius (2007:106-107), 'Evolutionary theory can say what roles contingency and causal laws play in the observable world'. Also, this scientific construct can say something about the kind of physical dynamics that launched the development of humankind and, consequently, something about the constituent nature of what it means to be human.

A second question one could also ask is: In what way does evolution matter to theology? Peterson (2000:224) clarifies that evolutionary theory impacts the following areas: concepts that deal with the origin of life and, therefore, creation. Questions concerning human origins and, hence, questions about original sin. Also, ideas about human nature and behaviour, including the future of people. This would include issues concerning the uniqueness of humans and understanding the image of God in people, including dealing with the formation and evolution of religious belief itself. The reason for making these theological claims is that soteriology and Christology are partly grounded in them.

In sum, the sciences matter to religion, yet religion is separate from the sciences because it possesses its own norms, traditions and assumptions. In this sense, choices do not need to be made between evolution and religion, but rather 
between good and bad evolutionary theory and good and bad religious beliefs. Admittedly, this could be a tough choice but eventually a more rational and gratifying one.

\section{Conclusion}

At the beginning of this article, it was stated that the idea of creation was taken from a classical Christian worldview. Moreover, as science progressed in its investigation of creation, it has imposed many of its findings on the biblical view of creation. In fact, science has generated doubts about the validity of Christianity as a viable worldview. This circumstance has forced evangelical theologians to put forward from scripture counterarguments to evolutionary arguments about the origin of the cosmos and life on earth. The consequence is a seemingly increasing mutual alienation between scientists and theologians.

The authors of this article have constructively responded by noting that numerous scientists study nature and its impact on humankind and rethink many of the evolutionary views being posited today in academic journals and other forms of discourse. Indeed, within the first decade of the 21st century, a series of fruitful efforts emerged to bridge the gulf that has developed between these sciences and theology. The authors also explained that Darwin was personally aware that his theory of evolution had notable problems. Yet, in all fairness to him, the authors pointed out that his theory was based on three reasonable assumptions for a Christian to concur with.

In the course of their deliberations, the authors observed that inevitably evolution matters to theology. By way of example, some of Darwin's theories can be scripturally validated. For this reason, it is misguiding to question whether Darwin's theory of evolution by natural selection has any value or whether it should be studied from a biblical perspective. The authors think that if evolutionary theory is interpreted theistically, it could possibly enhance one's understanding of the magnitude of God's 'fully gifted creation' (Van Till 1999:161). In closing, it is not surprising that many in the science-religion dialogue have turned their attention to precisely the kinds of issues raised in this article and will continue to do so in the future.

\section{Acknowledgements}

\section{Competing interests}

The authors declare that they have no financial or personal relationship(s) which may have inappropriately influenced them in writing this paper.

\section{Authors' contribution}

All authors contributed equally to this work.

\section{Ethical considerations}

The authors confirm that ethical clearance was not needed or required for the study.

\section{Funding information}

This research received no specific grant from any funding agency in the public, commercial or not for profit sectors.

\section{Data availability}

Data sharing is not applicable to this article as no new data were created or analysed during this study.

\section{Disclaimer}

The views and opinions expressed in this article are those of the authors and do not necessarily reflect the official policy or position of any affiliated agency of the authors.

\section{References}

Alexander, D.R., 2008, Creation or evolution: Do we have to choose? Monarch Books, Oxford.

Barbour, I.G., 2000, When science meets religion, Society for Promoting Christian Knowledge, London.

Barker, K.L. \& Burdick, D.W. (eds.), 1985, NIV Study Bible, Zondervan, Grand Rapids, MI. Barrett, P., 2004, Science and theology since Copernicus, T\&T Clark International, London. Bleier, R., 1986, Feminist approaches to science, Pergamon, New York, NY.

Borg, M.J., 2003, The heart of Christianity: Rediscovering a life of faith, Harper Collins Publishers, San Francisco, CA.

Case-Winters, A., 1997, 'The question of God in an age of science: Construction of reality and ultimate reality in theology and science', Zygon 3(3), 351-375. https:// doi.org/10.1111/0591-2385.00096

Clifford, A.M., 1994, 'Postmodern scientific cosmology and the Christian God of creation, Duquesne University', Horizons 21/1, 62-84. https://doi.org/10.1017/ S0360966900027936

Collins, C.J., 2003, Science and faith: Friends or foe?, Crossway Publishers, Wheaton, IL.

Collins, C.J., 2011, Did Adam and Eve really exist? Who they were and why you should care, Crossway Publishers, Wheaton, IL.

Darwin, C. (ed.), 1996, Gillian Beer, The origin of species, U Press, Oxford.

Davies, J.J., 1993, Evangelical ethics, P\&P Publishing, Phillipsburg, NJ.

Dixon, T., 2008, Science and religion: A very short introduction, Oxford University Press, New York, NY.

Draper, J.W., 1874, History of the conflict between religion and science, D. Appleton, New York, NY.

Enns, P., 2012, The evolution of Adam: What the Bible does and doesn't say about human origins, Baker Books, Grand Rapids, MI.

Ferngreen, J.B., 2002, Science and religion: A historical introduction, John Hopkins University Press, Baltimore, MD.

Floyd, C., 1999, 'A trick of the light: Richard Dawkins on science and religion', Science and Spirit 10, 24-31.

Giberson, K.W. \& Collins, F.C., 2011, The language of science and faith, IVP Books, Downers Grove, IL.

Gould, S.J., 2001, The book of life, W. W. Norton, New York, NY.

Gray, A., 1878, Darwinian: Essays and reviews pertaining to Darwinism, D. Appleton, New York, NY.

Green, M., 2004, The empty cross of Jesus, Kingsway Communications, Eastbourne.

Grudem, W., 1994, Systematic theology, Zondervan, Grand Rapids, MI.

Ham, K., 1987, The lie: Evolution, Master Books, Arkansas.

Harding, S., 1986, The scientific question in feminism, Cornell University Press, Ithaca, NY.

Johnson, G.S., 1998, Did Darwin get it right: Catholics and the theory of evolution, Our Sunday Visitor Publishing, Huntington, IN

Kennedy, P., 2006, A modern introduction to theology: New questions for old beliefs, I.B. Taurus Publisher, London, UK.

Kuhn, T., 1962-1970, The structure of scientific revolutions, 2nd edn., University of Chicago Press, Chicago, IL.

Lioy, D., 2011, Evolutionary creation in Biblical and theological perspective, Peter Lang, New York, NY.

Marshall, C.B., 1998, Genesis, Geneva Press, Louisville, KT.

McGrath, A.E., 2004, The science of God, T\&T Clarke International, New York, NY.

Moore, J., 1979, The post-Darwinian controversies, U Press, Cambridge, MA. 
Munro, A., 2004, 'The earth: An intimate history', The British Journal of General Practice 54(504), 563.

Nelson, P. \& Reynolds, J.M., 1999, 'Young earth creationism', in S. Gundry, J. Moreland \& J. Reynolds (eds.), Creation and evolution, pp. 41-102, Zondervan, Grand Rapids, MI.

Numbers, R.L. (ed.), 2009, Galileo goes to jail: And other myths about science and religion, First Harvard University Press, Cambridge, MA.

Paley, W., 1809, Natural theology, 12th edn., S. Hamilton, Surrey.

Pannenberg, W., 1988, 'The doctrine of creation and modern science', Zygon 23(1), 1-21. https://doi.org/10.1111/j.1467-9744.1988.tb00615.x

Peacocke, A., 1984, Intimations of reality: Critical realism in science and religion, IN University of Notre Dame, Dame Press, Notre Dame, IN.

Peterson, R.G., 2000, 'Think pieces: Whose evolution? Which theology?', Zygon 35(2), 221-232. https://doi.org/10.1111/0591-2385.00273

Platinga, A., 2011, Where the conflict really lies: Science, religion and naturalism, Oxford University Press, New York, NY.

Polkinghorne, J., 1998, Science and theology: An introduction, Fortress Press, Minnesota, MN.

Popper, K.R., 1994, Knowledge and the body-mind problem: In defence of interaction, M.A. Notturno (ed.), TJ Press, Cornwall.

Pretorius, M., 2007, 'Understanding reality: Exploring the interaction between theology and science, with special reference to a theistic presupposition to certain worldviews', Ph.D. dissertation, University of Pretoria, Pretoria.

Pretorius, M., 2011, 'The creation and fall of Adam and Eve: Literal, symbolic, or myth?', Conspectus 12(2), 161-184.

Ratzsch, D., 1996, The battle of beginnings, Intervarsity Press, Downers Grove, IL.
Rhodes, R., 2004, The 10 things you should know about the creation vs. evolution debate, Harvest House Publishers, Eugene, Oregon, OR.

Rolston, H., 2004, Science and theology news, October, pp. 1-2.

Ross, H., 2009, More than a theory, Baker Books, Grand Rapids, MI.

Ruse, M., 1997, Monad to man: The concept of progress in evolutionary biology, Harvard University Press, Cambridge, MA.

Russell, C.A., 1985, Cross-currents: Interaction between science \& faith, Inter-Varsity Press, London.

Schopf, J.W., 2011, 'The paleobiological record of photosynthesis', Photosynthesis Research 107(1), 87-101. https://doi.org/10.1007/s11120-010-9577-1

Schwartz, H., 1981, 'The significance of evolutionary thought for American protestant theology: Late nineteenth-century resolutions and twentieth-century problems', Zygon 16(3), 261-284. https://doi.org/10.1111/j.1467-9744.1981.tb00418.x

Spangenberg, J.J., 2003, 'Can a major religion change? Reading Genesis 1-3 in the twenty-first century', Verbum et Ecclesia 28(2), 259-279. https://doi.org/10.4102/ ve.v28i1.107

Stedman, R.C., 1995, In the beginning, Discovery Publishing, Palo Alto, CA.

Toulmin, S., 1982, The return to cosmology: Post modern science and the theology of nature, University of California Press, Berkley, CA.

Van Till, H.J., 1999, 'The fully gifted creation: "Theistic evolution"', in J.P. Moreland \& J.M. Reynolds (eds.), Three views on creation and evolution, pp. 161-218, Zondervan, Grand Rapids, MI.

Ward, K., 1998, Faith \& the new millennium, Fontana, Oxford.

White, A.D., 1896, A history of the warfare of science with theology in Christendom, D. Appleton, New York, NY. 